\title{
Social upheaval in ancient Angkor resulting from fluvial response to land use and climate variability
}

\author{
Dan Penny
}

\section{Recent archeological and paleoclimatic work indicate that the demise of Angkor - the world's largest pre-industrial city - was related to tight feedbacks between climatic variability, massive infrastructure, extensive land use, and water and sediment flux.}

\begin{abstract}
Angkor, in present-day Cambodia, was primate city to the sprawling Khmer empire from the $9^{\text {th }}-15^{\text {th }}$ century AD. Recent and ongoing mapping exercises (Evans et al. 2007; Pottier 1999) have demonstrated that Angkor covered an area in excess of $1000 \mathrm{~km}^{2}$ (Evans et al. 2007). At its peak in the $11-12^{\text {th }}$ centuries $A D$, the city supported a population of several hundred thousand people. The scale of the settlement implies an enormous environmental footprint, with the widespread conversion of primary forest to intensive bunded rice agriculture, and the systematic modification of natural rivers to stifle the seasonal flood pulse and feed massive reservoirs.
\end{abstract}

\section{Disrupting infrastructures}

Angkor developed a large infrastructural system to manipulate surface water and sediment flux (Fig. 1). By the $13^{\text {th }}$ century, the elaborate system of canals, embankments, ponds and reservoirs had become massive, deeply interdependent, brittle and sclerotic (Groslier 1979). In fact, the system had become so large and so complex that it began to exert an inertial force (Fletcher 2011) over the people that built it by effectively reducing the range of strategies they might use in changing circumstances (Groslier 1979) - an historical example of Graham's "disrupting in frastructures" (Graham 2009). Archeological research within the remains of the system has identified numerous attempts to modify or even destroy existing infrastructure, presumably to maintain some aspect of its function as the system began to break down (Buckley et al. 2010; Fletcher et al. 2008; Lustig et al. 2008; Penny et al. 2005).

Angkor was established on an extremely low relief catchment. Sediment and nutrient flux were therefore controlled by population size and the nature of land-use rather than by slope movement or mass wasting (Wasson 1996). However, the effect of extensive forest conversion to intensive rice agriculture is not clearly reflected in accelerated rates of soil loss and/or sediment accumulation.
Equally, there is no empirical evidence to suggest a mechanistic link between accelerating soil erosion in the catchment and the demise of the settlement. In fact, rates of sediment accumulation in depositional basins throughout Angkor are low, an average of $<1 \mathrm{~mm} \mathrm{a}^{-1}$, during the Angkorian period. In some cases these were very large basins, the largest being $16 \mathrm{~km}^{2}$ in area, with contribution areas in excess of $200 \mathrm{~km}^{2}$ (Penny et al. 2005). Bunded rice agriculture mimics natural wetlands, and on a low-relief alluvial plain such as in Angkor, extensive agriculture of this kind represents both a sink for sediment and particulate-bound nutrients and an effective buffer between the catchment and its fluvial network. It may be, then, that despite its size the type of land-use at Angkor and the nature of its catchment mitigated the loss of soil from catchment slopes to river channels and canals.

\section{Drought and floods}

More dramatic evidence for changing sediment flux is apparent within the network of channels and canals itself. Ad hoc, probably quite localized, modifications had been made to the infrastructural network to maintain water flow and function during prolonged drought. However, these changes made the structures more vulnerable to erosion when a particularly intense summer monsoon occurred. The demise of Angkor as a viable city coincides with prolonged ENSO-related summer monsoon failure in the mid $14^{\text {th }}$ and early 15th centuries (Buckley et al. 2010; Cook et al. 2010). While evidence of drought is reported at Angkor (Day et al. 2012), the most dramatic physical evidence from this period relates, counter-intuitively, to extreme flood events. Indeed, Buckley et al. (2010) indicate that long periods of weak summer monsoon rainfall were punctuated by extremely wet years - six of the twenty wettest years of the past millennium occurred during these multi-decadal drought episodes. The abrupt reversions to intense summer monsoon rainfall triggered a destructive succession, including deep incisions in the middle reaches of the Siem Reap canal in the order of 5-6 meters, in-filling of canals and channels in the lower reaches with relatively coarse, cross-bedded sands, and the avulsion of the Siem Reap canal (Buckley et al. 2010; Lustig et al. 2008).

\section{Tonle Sap Lake}

Angkor's failing water management network resulted in an increased flux of particulate-bound phosphate and sediment to Tonle Sap Lake, with implications for lacustrine ecology and sedimentation rates in the lake.

Sedimentation in Tonle Sap Lake itself effectively ceased in the middle of the Holocene when the lake became so shallow that winddriven mixing prevented net sediment accumulation (Penny 2006). Since that time, the sequestration of suspended sediment from the Mekong River, in the order of $5.6710^{9}$ kg per annum into Tonle Sap, has occurred preferentially on the northern side of the lake (Kummu et al. 2008) due to winnowing of suspended sediment by the extensive swamp forest communities that occur there. This has created a "ridge-and-swale" morphology observed also in other large lake basins (Albert et al. 2005).

Any significant increase in the flux of sediment from Angkor to Tonle Sap Lake due to the destabilization of the water management network is likely to have contributed to the lateral accretion of the basin in the area upstream of the depositional loci. Within the sediment of the backswamps along this shoreline the transition from well-sorted siliciclastic mud to primarily organic sediment can be taken to represent the isolation of the backswamp from the main lake during the dry season following the development of the lakeward ridge. Radiocarbon ages at the transitional boundary from site Boeng Prech Sramoch post-date the $17^{\text {th }}$ century $(110 \pm 40$ and $180 \pm 40{ }^{14} \mathrm{C} \mathrm{BP}$, respectively), suggesting nearly $4 \mathrm{~km}$ of horizontal progradation since that time. It is unclear if this accretion 

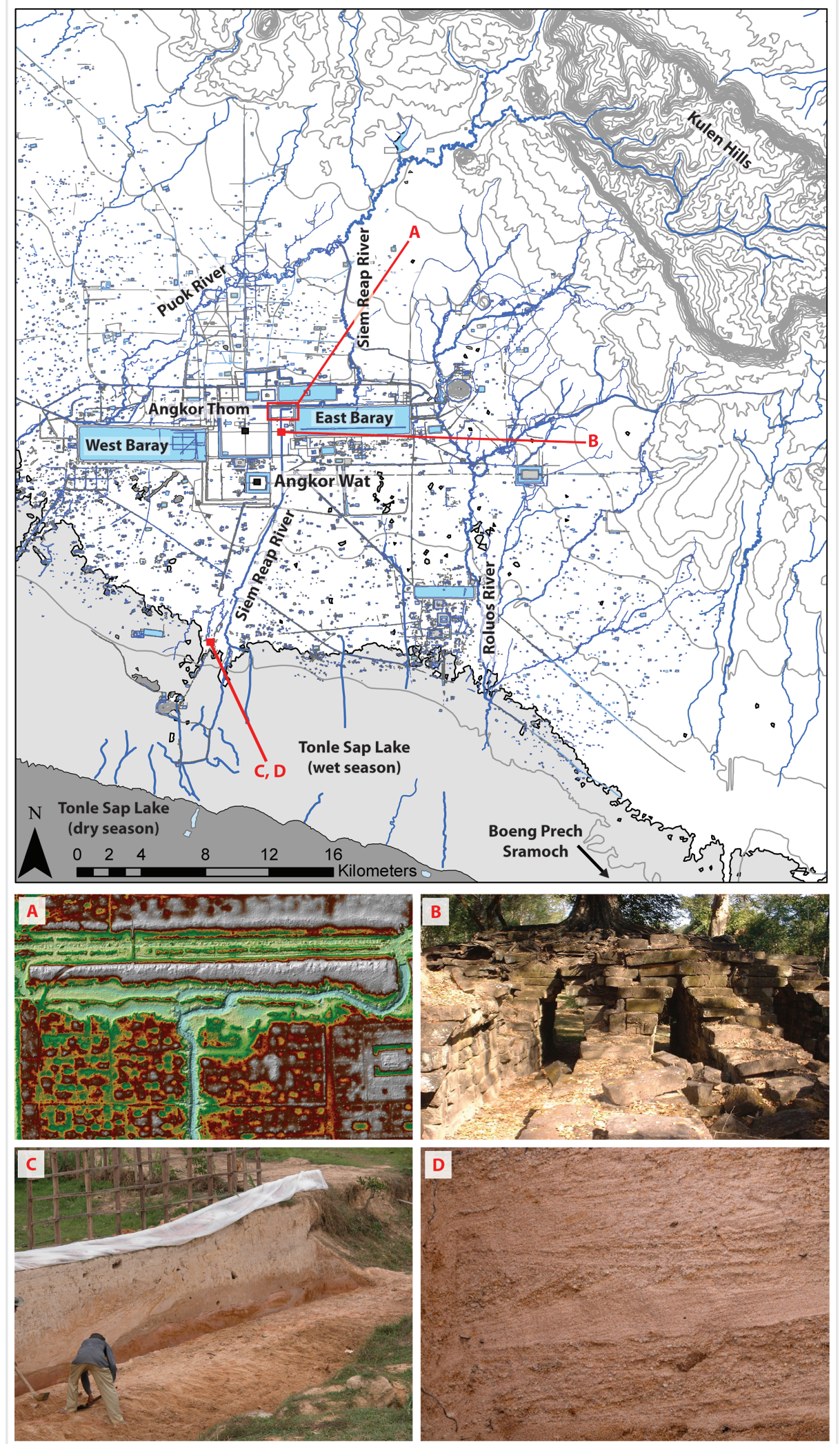

represents the storage of material eroded from Angkor's infrastructure, a change in volume of suspended sediment yielded to the lake from the Mekong River, or a conflation of the two phenomena.

\section{Collapse and transformation}

In the case of Angkor, the interaction between extensive land-use and climatic variability triggered dramatic changes in both the canal system and, through nickpoint migration, the fluvial network to its north. Given that Angkor's agriculture, and perhaps even the legitimacy of the administration, was closely tethered to the management and distribution of surface waters, the social outcomes of these fluvial responses were profound and resulted in unprecedented social upheaval.

By the end of the $15^{\text {th }}$ century, Angkor and its city-region had collapsed, abandoned by the administration and the elite in favor of a succession of cities in the vicinity of the modern Cambodian capital of Phnom Penh. The elite were followed, it is presumed, by an urban diaspora from the Angkorian cities to the new "Middle Period" centers.

Ultimately, Angkor's massive, brittle and inter-dependent water management infrastructure failed to suppress climate impacts on biogeochemical flux from catchments. Instead, it both sensitized the attendant fluvial networks to ENSO-related climatic variability and reduced the range of adaptive strategies available to the administration.

\section{AFFILIATION}

School of Geosciences, The University of Sydney, Australia

\section{CONTACT}

Dan Penny: dan.penny@sydney.edu.au

\section{REFERENCES}

Buckley BM et al (2010) Proc Nat Acad Sci USA 107: 6748-6752

Cook ER et al. (2010) Science 328: 486-489

Evans D et al. (2007) Proc Nat Acad Sci USA 104: 14277-14282

Fletcher R et al. (2008) Antiquity 82: 658-670

Groslier BP (1979) Bull Ec Fr Extr Orient 66: 161-202

Figure 1: Archeological map of Greater Angkor, emphasizing the complexity of the water management network, and the articulation of canals and rectilinear reservoirs with the natural fluvial network. Data from Evans et al. (2007), Pottier (1999), Mekong River Commission, Japanese International Cooperation Agency. (A) False color digital terrain model derived from a LiDAR point cloud. Erosion caused by uncontrolled water flow through the canal network is clearly apparent as pale blue and green colors. Such water flow events triggered significant vertical incision of the canal bed. Image courtesy of Khmer Archaeology LiDAR Consortium/Damian Evans. (B) Spean Thma (lit. stone bridge), immediately east of the famous walled enclosure of Angkor Thom, once spanned the Siem Reap canal. Destabilization of the canal network during the $14^{\text {th }}$ century caused the canal to incise several meters below the bridge, destroying its eastern half and leaving its western half, seen here, abandoned on the dry canal bed. (C) Many of the ancient canals south of the city, presumably critical in linking the ports at the edge of the lake to the markets in the central urban area, are now filled with several meters of sediment, including coarse ( $28 \%$ by weight) to very-coarse (17\%) cross-bedded sand and gravel (D), with the largest clasts $>-5 \varphi_{1}>32 \mathrm{~mm}$ in diameter. These deposits indicate an increase in the flux of sediment and other materials from the canal network, and flows of sufficient energy to entrain them. Post-dating the $14^{\text {th }}$ century, these events broadly coincide with multi-decadal scale drought. 